\title{
Иностранные боевики-террористы с Северного Кавказа: понимание влияния Исламского государства в этом регионе
}

\section{Даша Никольсон}

Резюме: На пике влияния 'Исламского государства' в Сирии в его рядах находятся примерно 30000 иностранных боевиков, и четверть из них прибыли из России (Чечня и Дагестан) и стран бывшего Советского Союза. В этой статье рассматривается феномен иностранных боевиков-террористов с Северного Кавказа и его последствия для безопасности Северного Кавказа, Российской Федерации и всего мира. Число боевиков, возвращающихся в этот регион из Сирии, точно не известно. Тем не менее, по возвращении домой иностранные боевики из первой волны смогли создать себе репутацию и воспользоваться ею, расширить свой опыт, умения и сети, создав разные джамаат и, в одном случае, 'джихадистскую частную военную компанию'. Если представится возможность, боевики второй волны, вероятнее всего, продолжат воевать на Кавказе, но если они не смогут вернуться домой, они могут начать наносить удары где угодно.

Ключевые слова: русские, Северный Кавказ, Исламское государство, иностранные боевики-террористы, ИБТ, антитеррористическое законодательство, контртеррористические операции.

Нам стыдно, что мы отправляемся в Сирию во время, когда Кавказ все еще оккупирован, но молодые люди возвращаются сюда после того, как они прошли курс подготовки.

- Источник ВВС, 'близкий’ к чеченским боевикам 


\section{Введение}

В сентябре 2014 года Совет безопасности Организации Объединенных Наций единогласно принял резолюцию 2178, касающуюся «существенной и разрастающейся» угрозы, которую представляют собой иностранные боевики-террористы (ИБТ). Такими являются лица, «которые отправляются в Государство, отличное от Государства их проживания или их национальности с целью совершения, планирования или подготовки, или участия в террористических актах, или предоставляющие, или получающие террористическую подготовку, в том числе в связи с вооруженным конфликтом». ${ }^{1}$ ИБТ оказывают влияние на динамику конфликта - его неразрешимость, продолжительность и интенсивность и, кроме того, являются угрозой для своего «государства происхождения, государства транзита, государства следования и для зон в соседстве с вооруженным конфликтом, в котором они активно участвуют». ${ }^{2}$ С начала гражданской войны в Сирии, и особенно после июня 2014 года, момента прокламации 'халифата', тысячи вдохновленных боевиков из разных регионов отправились в Ирак и Сирию, чтобы присоединиться к Исламскому государству (ИГ) или к другим вооруженным экстремистским группировкам. ${ }^{3}$ Согласно докладу, опубликованному Группой Суфан в декабре 2015 года, число иностранных боевиков в Сирии достигло приблизительно 30 000, причем это лица из более 100 стран. ${ }^{4}$ В 2015 году первыми тремя национальностями с наибольшим числом ИБТ были тунисцы (6000), саудовцы (2500) и русские (2300), тогда как число выходцев из бывших республик Советского союза составляет 4700. ${ }^{5}$ В октябре 2015 российский президент Владимир Путин заявил, что от 5000 до 7000 боевиков из России и бывшего Советского Союза (БСС) отправились в Сирию, чтобы присоединиться к ИГ. ${ }^{6}$ Большинство этих боевиков выходцы из Северного Кавказа (Чечня и Дагестан), другие из Азербайджана и Грузии, а также из Средней Азии - из Казахстана, Кыргызстана, Таджикистана, Туркменистана и Узбекистана. Все они не только говорят по-русски, но и все унаследовали обиду за афгано-советский и пост-советские конфликты.

В этой работе сделана попытка рассмотреть феномен ИБТ с Северного Кавказа и его последствия для безопасности Северного Кавказа, Российской

1 Resolution 2178 (2014), adopted by the UN Security Council at its 7272 nd meeting, on September 24, 2014, S/RES/2178 (2014), http://www.un.org/en/ga/search/view_ doc.asp?symbol=S/RES/2178\%20(2014).

2 UN SC Resolution 2178.

3 Global Coalition, Foreign Terrorist Fighters - Trends and Dynamics, March 3, 2017, http://theglobalcoalition.org/en/foreign-terrorist-fighters-trends-and-dynamics.

4 The Soufan Group, Foreign Fighters. An Updated Assessment of the Flow of Foreign Fighters into Syria and Iraq, December 2015, http://soufangroup.com/wp-content/ uploads/2015/12/TSG_ForeignFightersUpdate3.pdf.

5 The Soufan Group, Foreign Fighters.

6 The Soufan Group, Foreign Fighters. 
Федерации и мира в целом. Для этого будут рассмотрены мотивы ИБТ с Северного Кавказа, группировки, за которые они воюют, и их связь с внутренней террористической ситуацией.

К 2017 году общее число ИБТ в Сирии и Ираке снизилось как за счет боевых потерь, так и за счет уменьшившегося потока иностранных боевиков к зоне конфликта. К примеру, по данным ИНТЕРПОЛ, в 2016 году считалось, что число ИБТ в регионе составляло $15000 .^{7}$ Среди прочего, данный спад в мобилизации ИБТ относят на счет усиления мер по контролю со стороны стран-членов ООН, военного давления на группировки и «финансовый упадок» ИГ. Жизненно важные источники доходов этой организации связаны с ее территорией: налоги и сборы; нефть; грабежи, конфискации и штрафы. ${ }^{8}$ Потери территории и последовавшее функционирование на «кризисном бюджете» стали причиной увеличения числа дезертиров, трудностей при вербовке и расширения внутренней коррупции и краж. ${ }^{9}$ Более того, в результате этого ИБТ имеют низкий боевой дух, многие из них «упаковывают вещи» и "хотят бежать». ${ }^{10}$ Конечно, уменьшению общей численности способствовал не только сниженный приток ИБТ, но так же и «обратный поток» - ИБТ, которые возвращаются в свой родной регион или переезжают в третью страну. Например, есть предположение, что к декабрю 2016 года приблизительно 30 \% ИБТ из Европы вернулись в свои родные страны. ${ }^{11} \mathrm{C}$ учетом всего этого, (общее) большое число ИБТ с Северного Кавказа, участвующих в конфликте, вызывает беспокойство. Эти ИБТ вернутся в свои родные регионы с мирными целями или со злыми намерениями? Предпочтут ли они остаться в зоне конфликта и, возможно, присоединиться к другим террористическим организациям из-за нарастания давления на ИГ? Или они перейдут в третье государство, а возможно, перегруппируются и примут

7 Tanya Mehra, "Foreign Terrorist Fighters: Trends, Dynamics and Policy Responses," ICCT Policy Brief (The Hague: International Center for Counter-Terrorism, December 2016), https://icct.nl/wp-content/uploads/2016/12/ICCT-Mehra-FTF-Dec2016-1.pdf.

8 Stefan Heißner, Peter R. Neumann, John Holland-McCowan, and Rajan Basra, Caliphate in Decline: An Estimate of Islamic State's Financial Fortunes (London: King's College, International Center for the Study of Radicalization and Political Violence, 2017), https://icsr.info/wp-content/uploads/2017/02/ICSR-Report-Caliphate-in-Decline-AnEstimate-of-Islamic-States-Financial-Fortunes.pdf.

9 Kairat Umarov, "Letter dated 11 January 2017 from the Chair of the Security Council Committee pursuant to resolutions 1267 (1999), 1989 (2011) and 2253 (2015) concerning Islamic State in Iraq and the Levant (Da'esh), Al-Qaida and associated individuals, groups, undertakings and entities addressed to the President of the Security Council," S/2017/35, UN Security Council, January 13, 2017, https://documents-ddsny.un.org/doc/UNDOC/GEN/N17/000/13/pdf/N1700013.pdf.

10 Paul Wood, "The Truth About Islamic State: It's in Crisis!" The Spectator, January 9, 2016, https://www.spectator.co.uk/2016/01/the-truth-about-islamic-state-its-in-crisis; Martin Chulov, "Losing Ground, Fighters and Morale - Is It All Over for ISIS?" The Guardian, September 7, 2016, www.theguardian.com/world/2016/sep/07/losingground-fighter-morale-is-it-all-over-for-isis-syria-turkey.

11 Mehra, "Foreign Terrorist Fighters: Trends, Dynamics and Policy Responses." 
участие в другом конфликте? Теоретики по вопросам терроризма Кларк и Амарасингам прогнозируют несколько вариантов действий для транснациональных террористов. «Твердолинейные» ИБТ Исламского государства могут остаться в Сирии и Ираке. ${ }^{12}$ Некоторые могут попытаться присоединиться к «подпольному сопротивлению ИГИС, 2.0», которое со временем может создать тайную террористическую организацию. ${ }^{13}$ Другие могут присягнуть на верность другим группировкам в зоне конфликта и, в итоге, пойти на сближение с Аль-Каидой. ИБТ, которым по разным причинам нельзя вернуться в страну своего происхождения - 'независимые', 'свободные агенты', - могут создать «когорту не имеющих гражданства джихадистов» и перейти в третью страну с целью продолжать джихад. ${ }^{14}$ И последнее, ИБТ, которые вернутся в свои родные страны, могут оказаться «разочарованными», «отошедшими, но не разочарованными» или «готовыми к действию». ${ }^{15}$

ИБТ с Северного Кавказа являются членами весьма разрозненной оппозиции, противостоящей сирийским правительственным силам. Большинство из них находится в рядах ИГ, другие присоединились к ан-Нусра, а остальные являются участниками многочисленных фракций в зоне боев. У многих ИБТ с Северного Кавказа имеется предыдущий боевой опыт - к примеру, из Афганистана, из Грузии, из Чечни - и репутация неудержимых бойцов. Действительно, 'чеченские' боевики (и вообще боевики с Северного Кавказа) похоже, воспринимаются как 'элита боевиков', заслуживающие уважения. ${ }^{16}$ Такая репутация в использовании насилия, вероятно, была создана в некоторой мере такими личностями, как Абу Омар аль-Шишани (Тархан Батирашвили - возможно, умерший в 2016 году). Омар (Тархан) родился в деревне в Панкисском ущелье, находящемся недалеко от грузиночеченской границы. Его отец грузин, а мать этническая чеченка (кист). Он служил в разведывательном подразделении грузинской армии, пока не заболел туберкулезом. В 2010 году он угодил в тюрьму за хранение оружия. Его старший брат, Тамаз, участвовал в чеченских войнах, и после этого также присоединился к ИГ. Омар стал известной фигурой оппозиции, командовал таким боеспособным отрядом, как Джаиш аль-Мухаджирин валь-Ансар (Армия эмигрантов и помощников) в 2013 году. Затем в том же году Омар аль-Шишани стал командующим северной армии ИГ, командиром чечен-

12 Colin P. Clarke and Amarnath Amarasingham, "Where do ISIS Fighters Go When the Caliphate Falls? They Have Options," The Atlantic Daily, March 6, 2017, https://www.theatlantic.com/international/archive/2017/03/isis-foreign-fighterjihad-syria-iraq/518313/.

13 Clarke and Amarasingham, "Where do ISIS Fighters Go When the Caliphate Falls?"

14 Clarke and Amarasingham, "Where do ISIS Fighters Go When the Caliphate Falls?"

15 Clarke and Amarasingham, "Where do ISIS Fighters Go When the Caliphate Falls?"

16 Joanna Paraszczuk, "'IS's Abu Waheeb Really Liked North Caucasians' \& Notes on Circassians and Shishanis," From Chechnya to Syria, October 21, 2016, http://www.chechensinsyria.com/?p=25267. 
ского и северокавказского батальона ИГ и командиром специальных отрядов ИГ. ${ }^{17}$ В целом ИБТ с Северного Кавказа сосредоточены в северной Сирии - в провинциях Латакия и Идлиб, в Алеппо и в районах на турецко-сирийской границе Рас аль-Айн и Тал аль-Абьяд. ${ }^{18}$

Учитывая большое число лиц, принимающих участие в конфликте и историю конфликта в регионе, ИБТ с Северного Кавказа в долгосрочном плане, вероятно, являются серьезной угрозой безопасности. Поэтому важно изучить мотивы их участия в войне, фракции/организации, за которые они воюют, степень влияния на них про-джихадистской пропаганды и некоторые их отличительные характеристики (предыдущий боевой опыт, связи с другими террористическими организациями и т.д.).

\section{Мотивы для того, чтобы воевать в Сирии}

Без всякого сомнения, мотивы ИБТ с Северного Кавказа - как и боевиков из других регионов - самые разные. Однако, одним из наиболее важных общих мотивов, отличающим эту группу лиц, является то, что гражданская война в Сирии предоставляет альтернативный театр военных действий для борьбы против российского государства. ${ }^{19}$ Конфликт на Северном Кавказе, и в частности в Чечне, имеет долгую историю и крутится вокруг проблемы получения независимости от центрального правительства. Эту борьбу можно проследить назад во времени вплоть до имперской России, и она охватывает две последние кровавые русско-чеченские войны и все волнения в целом в данном регионе. Затянувшееся состояние конфликта (и официальные попытки для его нормализации) создало и оставило после себя тяжелые социальные проблемы и огромное наследие обид. Они становятся горючим для сопротивления на Северном Кавказе, для боевиков и экстремистов. Однако, повстанцы или боевики имеют очень ограниченную возможность 'продолжать борьбу' в регионе. К примеру, в Чечне из-за прокремлевского правительства, возглавляемого бывшим мятежником Рамзаном Кадыровым. Невозможность 'продолжать борьбу' на Северном Кавказе в сочетании с поддержкой, которую Москва оказывает режиму Асада, являются побудительными факторами для присоединения к борьбе в Сирии. Как открыто подтвердил Омар Шишани в интервью, опубликованном в EA Worldview в декабре 2013, 'Кавказский эмират' (КЭ) 'послал' боевиков

17 «Выходцы с Кавказа в рядах ИГ (ИГИЛ)», Кавказский Узел, 21 февраля 2017, https://www.kavkaz-uzel.eu/articles/251513.

18 Emil Souleimanov and Megan Ouellette, "The Participation of North Caucasian Jihadists in the Syrian Civil War and its Security Implications," Rubin Center, February 22, 2015, www.rubincenter.org/2015/02/the-participation-of-north-caucasianjihadists-in-the-syrian-civil-war-and-its-security-implications.

19 Dmitry Shlapentokh, "The North Caucasian Resistance and the Syrian Crisis," Insight 83 (Singapore: Middle East Institute, National University of Singapore, 3 December 2012), https://mei.nus.edu.sg/publication/insight-83-the-north-caucasian-resistanceand-the-syrian-crisis/. 
в Сирию, чтобы они прошли подготовку. Задача состояла в том, чтобы они потом вернулись 'подготовленными' для борьбы с Россией на Северном Кавказе. В других интервью Шишани говорит о желании «ослабить одного из ключевых союзников Асада» и отмечает, что "джихад против русских и их баасистского союзника» были одним из основных мотивов для того, чтобы воевать в Сирии. ${ }^{20}$

Между прочим, контртеррористические операции (КТО), проводимые российскими правительственными и специальными силами, и их последствия иной раз не оставляют отдельным лицам никакого выбора, кроме как уйти из этого региона и устроиться где-то в другом месте. ${ }^{21}$ Например, таким был случай с Абдулкадыровым - «который воевал здесь в горах» - из Дагестана; за ним охотились местные органы охраны правопорядка и боевики, и для того, чтобы бежать и от тех, и от других, он отправился воевать в Сирию. ${ }^{22}$ Перед олимпийскими играми в Сочи в 2014 для джихадистов направляющихся в Сирию, и для мирных консервативных мусульманских семей популярным направлением стала Турция. ${ }^{23}$ Так же, в 2016 году «тысячи чеченцев» направлялись в Германию через Польшу с целью получить убежище. ${ }^{24}$ В июне 2016 число российских граждан, ходатайствующих на получение убежища в Германии, дошло до 1835, из которых предположительно $90 \%$ были чеченцами; и из 6 100, которые хотели убежища в Польше - 94 \% были с Северного Кавказа. ${ }^{25}$ Согласно руководителю Бранденбургского централь-

20 Jack Moore, "The Ginger Jihadist of Mosul: Omar Shishani the Chechen 'General'," International Business Times, June 24, 2014, http://www.ibtimes.co.uk/gingerjihadist-mosul-omar-al-shishani-chechen-general-1452232. See also Thomas Grove and Mariam Karouny,"Militants from Russia's North Caucasus join "Jihad" in Syria," Reuters, March 6, 2013, http://www.reuters.com/article/us-syria-crisis-russiamilitants-idUSBRE9251BT20130306; and Erin McClam, "Rising Star of ISIS Has Chechen Background and Fierce Reputation," RMSMC blog, July 2, 2014, https://rmsmcblog.wordpress.com/2014/07/11/more-on-omar-al-shishani-part-ii.

21 Елена Милашина, «Халифат? Приманка для дураков!», Новая газета, 29 июля 2015, www.novayagazeta.ru/articles/2015/07/29/65056-171-halifat-primanka-dlyadurakov-187. Милашина рассматривала город Новосаситли в Хасавюртовском районе Дагестана. В свою статью она включила описание случаев нескольких лиц, отправившихся воевать в Сирии.

22 Милашина, "Халифат? Приманка для дураков!».

23 International Crisis Group, "The North Caucasus Insurgency \& Syria: An Exported Jihad?" Europe Report no. 238, March 16, 2016, https://www.crisisgroup.org/europecentral-asia/caucasus/north-caucasus/north-caucasus-insurgency-and-syriaexported-jihad.

24 Alix Culbertson, "Thousands of Chechens Slipping Through Unmanned Border in Latest German Migrant Crisis," Express, August 24, 2016, http://www.express.co.uk/ news/world/703337/Chechen-migrants-unmanned-German-border-Poland.

25 Janosch Delcker, "Germany's New Problem Border: Poland," Politico, August 24, 2016, http://www.politico.eu/article/police-officials-concerned-about-migrants-crossinggerman-polish-border-terrorism-migration. 
ного отдела регистрации иностранцев, Франку Нюрнбергеру, такая же волна имела место в 2013, за которой последовал спад в 2014 и увеличение в $2016 .^{26}$

Конечно, другим важным мотивационным фактором является религия. Так же, как во время чечено/дагестано/ингушского сопротивления религия служила фактором для привлечения иностранных боевиков в Чечню, сейчас она используется как объединяющий фактор выходцами с Северного Кавказа, воюющих в Сирии. Многие молодые мужчины были привлечены к «участию в сирийском джихаде ${ }^{27}$ и были убеждены, что взяться за оружие является их долгом. С одной стороны, они считают алавитский (неортодоксальная секта шиитского ислама) режим Асада «не по-настоящему мусульманским» и "еретическим». ${ }^{28}$ Во-вторых, этот режим воспринимается как «ключевой союзник России» на Ближнем Востоке. Поэтому, это не только возможность для участия в джихаде, но так же является обязанностью русскоговорящих мусульман присоединиться к своим угнетенным братьям в Сирии. ${ }^{29}$ Большинство ИБТ с Северного Кавказа являются салафистами. Другие проявляют “суннитскую солидарность» под влиянием образов и пропаганды случаев мусульман-суннитов раненных/замученных/убитых алавитским режимом «неверных». ${ }^{30}$ Таким образом, театр военных действий в Сирии предоставляет ИБТ с Северного Кавказа возможность одновременно воевать против российского государства и его интересов, и воевать с противниками ислама по всему свету. ${ }^{31}$

Кроме того, принимая участие в сирийской гражданской войне, неопытные ИБТ могут приобретать боевой опыт и устанавливать связи - а затем участвовать во внутренних мятежах или террористической деятельности по возвращению домой. Дополнительно, участие в конфликте дает возможность реконструкции собственной идентичности - выйти из жизни в бедности и безработице, где «учеловека не осталось ничего» и вступить в борьбу «за братьев по оружию» и за «благородное» дело. 32

Война в Сирии иллюстрирует восход «джихадистского интернационала», как называет этот феномен Марк Галеоти, боевики с готовностью переезжают из зоны одного конфликта в зону другого во имя вооруженного

26 Delcker, "Germany's New Problem Border: Poland."

27 Emil A. Souleimanov, "Globalizing Jihad? North Caucasians in the Syrian Civil War," Middle East Policy 21, no. 3 (Fall 2014), http://www.mepc.org/globalizing-jihad-northcaucasians-syrian-civil-war (21 August 2017).

28 Shlapentokh, "The North Caucasian Resistance and the Syrian Crisis."

29 Souleimanov and Ouellette, "The Participation of North Caucasian Jihadists in the Syrian Civil War and its Security Implications."

30 Souleimanov and Ouellette, "The Participation of North Caucasian Jihadists in the Syrian Civil War and its Security Implications."

31 Souleimanov, "Globalizing Jihad? North Caucasians in the Syrian Civil War."

32 Souleimanov and Ouellette, "The Participation of North Caucasian Jihadists in the Syrian Civil War and its Security Implications." 
джихада, вне зависимости от того, имеют ли они личную связь с конфликтом или нет. ${ }^{33}$ Во-первых, это можно увидеть в присутствии многочисленных фракций выходцев с Северного Кавказа и лиц из Средней Азии и Ирака (независимые или аффилированные с ан-Нусра). Во-вторых, в случае некоторых ИБТ с Северного Кавказа, это можно увидеть в смене союзов с разными вооруженными группами, действующими в этом регионе, на первом месте инициированной желанием воевать с режимом Асада для того, чтобы бороться с Россией. Таким примером является Омар Шишани, который в конечном итоге оказался в рядах ИГ. В-третьих, некоторые известные фигуры имеют историю участия в предыдущих конфликтах. Это, однако, феномен не новый - во время чеченских войн иностранные полевые командиры (среди прочих рожденные в Саудовской Аравии ибн Хаттаб и Абу Омар альСаиф) создавали свои команды на Северном Кавказе. Термин «джихадистский интернационал», следовательно, может быть использован для классификации ИБТ и обозначения тех, кто в потенциале более опасны для глобального гражданского общества из-за своей большей решительности, своего более широкого (потенциального/будущего) опыта и неизменной готовности продолжать борьбу независимо от личной связи с данным конфликтом.

Некоторые теоретики, например Рателле, утверждают, что боевики с Северного Кавказа можно разделить на две волны: те, кто отправились в Сирию в 2011-2013 из-за того, что они не могли продолжать борьбу в своем родном регионе; и те, кто прибыл в Сирию в 2014-2017, так как они «открыто решили» не воевать на Северном Кавказе и «присоединиться к международному джихадистскому фронту». ${ }^{34}$ Эту динамику в некоторой степени может объяснить соперничество между Имарат Кавказ (Кавказский эмират) и Исламским государством.

\section{Имарат Кавказ против Исламского государства}

Имарат Кавказ (ИК, также известная, как Кавказский эмират, или КЭ) является самопровозглашенной сепаратистской группировкой, которая стремится к созданию своего собственного Исламского государства на Северном Кавказе. ${ }^{35}$ Она была создана в 2007 году в период второй чеченской войны полевым командиром Доку Умаровым. Он провозгласил себя «эмиром муджахидов Кавказа», «лидером джихада» и «единственной законной

33 Mark Galeotti, "Chechen 'Jihadist International' Emerges in Syria," Russia Beyond the Headlines, April 15, 2013, https://rbth.com/opinion/2013/04/15/chechen_jihadist_ international_emerges_in_syria_25025.html.

34 Jean-François Ratelle, "North Caucasian Foreign Fighters in Syria and Iraq: Assessing the Threat of Returnees to the Russian Federation," Caucasus Survey 4, no. 3 (2016): 218-238.

35 «Имарат Кавказ», Кавказский Узел, 27 декабря 2016, https://www.kavkazuzel.eu/articles/158730. 
властью на всех территориях, на которых присутствуют муджахиды», объединяющей вооруженных джамаam. ${ }^{36} \mathrm{~K}$ моменту своего формирования эмират состоял из шести вилаятов (территориальных административных формирований): Дагестан, Нокчичо (Ичкерия), Галгайче (Ингушетия), Иристон (Северная Осетия), Ногай Степпе (Ставропольская территория) и объединенный вилаят Кабарда, Балкария и Карачай. Более того, Кавказский эмират имеет официальное представительство за границей - Векалат, - возглавляемое уполномоченным представителем муджахидов и Кавказского эмирата. ${ }^{37}$ Однако, в 2010 году, в соответствие с Омра ${ }^{38}$ \# 20, Доку Умаров упразднил Векалат. Далее, к 2010 году, КЭ был признан террористической организацией как Россией, так и США.

В то же время, уже в 2010 году, организация начала подвергаться внутренней фрагментации. К концу 2014 года, в связи со смертью Доку Умарова (официально объявленной Федеральной Службой Безопасности (ФСБ) в 2014 году) и последовавшей склоке по поводу назначения следующего руководства и позднее его устранения, штаб-квартира Кавказского эмирата перемещалась несколько раз. Действительно, вся организация стала даже еще более раздробленной и, возможно, пришла в состояние упадка. Некоторые эксперты (к примеру, Рощин) указывают на изменение террористической тактики КЭ- очевидно большее количество самоубийственных взрывов, совершаемых молодыми мужчинами и женщинами, что является признаком ухудшения дел организации. Осенью 2014 года Зайланабидов (руководитель вооруженной группы, действующей в Хасавюртовском районе Дагестана) присягнул на верность Абу Бакр аль-Багдади (руководителю ИГ). ${ }^{39}$ Его примеру последовали несколько руководителей вооруженных групп, которые призвали своих «братьев» сделать то же самое. Что важно, обещание верности к аль-Багдади в этом контексте требует, чтобы данное лицо отказалось от своей присяги КЭ. Эти действия затем были усугублены разногласиями между боевиками с Северного Кавказа. Сейчас, в 2017 году, КЭ практически не функционирует, поскольку большинство лидеров остающихся в России формирований были нейтрализованы.

В процессе развития конфликта в Сирии, начиная с 2011 и 2012, группы, возглавляемые ИБТ с Северного Кавказа в Сирии, были втянуты в борьбу между Аль-Каидой и ИГ за контроль над сирийской оппозицией. На практике, группы, которые появились в Сирии в первые два год конфликта, были тесно связаны с Кавказским эмиратом. Первый северокавказский джамаат в Северном Алеппо был под командованием чеченского боевика-ветерана, известного под именем Хамзат (первый эмир Имарата Кавказ с Сирии). По

\footnotetext{
36 «Имарат Кавказ».

37 «Имарат Кавказ».

38 Директива/Приказ.

39 «Имарат Кавказ».
} 
мнению Йоанны Паращук, это было «практически передовым постом ИК». ${ }^{40}$ В целом, Кавказский эмират оставался верным Аль-Каиде - по крайней мере, на первых этапах его операций. КЭ отличается от ИГ не только идеологически, организационно, в плане вербовки и в уровне насилия, которое он использует, но также и в том, как он функционирует. Он действует через то, что Орхан Дземал, региональный журналист, называет «ночным правительством» - параллельное правительство с чисто военной структурой, «осуществляющее управление людей, угнетенных тяжестью мира». ИГ, наоборот, восприняло "дневной» подход, убеждая целые семьи присоединиться к нему и начать новую жизнь. ${ }^{41}$

До 2015 года руководители КЭ выгоняли бы тех боевиков, кто присягал на верность аль-Багдади, и некоторые из них позже возвращались бы в Кавказский эмират. Для КЭ отсутствие харизматических лидеров, увеличивающаяся внутренняя раздробленность, нехватка финансов и трудности с вербовкой, возможно, сделали альтернативный исламистский нарратив более привлекательным, освобождая место для присутствия и власти ИГ.

Что интересно, КЭ в техническом плане имеет «вилаят» в Сирии, известный как Имарат Кавказ в Шаме. 8 июля 2015 года Салахуддин Шишани и группа боевиков, верные КЭ, обещали байа новому эмиру КЭ - Абу Усману Гимрински (Сулейманов). Абу Усман был убит в августе 2015 года в результате КТО, проведенной российскими правительственными силами. В декабре 2015 Салахуддин был смещен с поста эмира Имарата Кавказ в Шаме. Позже в 2016 ходу эта организация приняла участие в боях в южных пригородах Алеппо вместе с Джунуд аль-Акса ${ }^{42}$ и ан-Нусра. Однако, похоже, что на деле большинство боевиков там были сирийцами. ${ }^{43}$

23 июня 2015 года ИГ провозгласило формирование нового вилаята в российском Северном Кавказе. Эта декларация последовала за вереницей официальных клятв верности тысячи боевиков в данном регионе, являющихся отголоском клятв в 2014, таким образом обозначив упадок Имарата Кавказ и выявив необходимость оценить степень влияния ИГИС в этом регионе. В результате эффективной пропаганды ИГ против России и соседствующих с ней стран, к 2017 году русский стал третьим самым используемым

40 Joanna Paraszczuk, "1st Imarat Kavkaz Amir in Syria Fought Alongside Gelyaev in Chechnya, Died Fighting Alongside Ahrar," From Chechnya to Syria, July 21, 2016, http://www.chechensinsyria.com/?p=25171.

41 Как цитировано в Anna Borschevskaya, "The Islamic State Comes to Russia," Journal of International Security Affairs (Fall/Winter 2015): 27-32, доступно на https://www.washingtoninstitute.org/policy-analysis/view/the-islamic-statecomes-to-russia.

42 "Jund al-Aqsa," in Jihad Intel's "Database: Identifiers of Designated Islamic Terrorist Organizations," Middle East Forum, http://jihadintel.meforum.org/group/123/jundal-aqsa (21 August 2017).

43 Joanna Paraszczuk, "Arabic-Speaking Katiba Guraba Fighting Under Auspices of IK v Shame in South Aleppo," From Chechnya to Syria, March 10, 2016, http://www.chechensinsyria.com/?p=25028. 
языком в ИГ после английского и арабского. Даже есть журнал ИГ, выходящем на русском - Исток, и медиа платформа с наименованием Фурат Меdua.

\section{За кого сражаются выходцы с Северного Кавказа?}

Первые боевики с Северного Кавказа в Сирии приступили к активным действиям где-то в 2012 году, большинство из них сформировали северокавказские джамаат (группы). По некоторым сведениям было около 15-17 боевиков, и среди них были такие фигуры, как Омар аль-Шишани, Салахуддин аль-Шишани и Сайфулла аль-Шишани. ${ }^{44}$ Омар аль-Шишани и Сайфулла ушли, чтобы сформировать новую, относительно небольшую группу под наименованием Катиба Муджахирин, которая в 2013 могла слиться с двумя другими (арабские Ката'иб Хаттаб и Джаиш Мухаммад), чтобы создать Джаиш аль-Мухаджирин валь-Ансар. Однако, Хамзат вышел из КЭ, и позже начал сражаться вместе с Ахрар аль-Шам ${ }^{45}$ в Алеппо.

В процессе развития конфликта в Сирии число боевиков с Северного Кавказа, остальной России и Содружества Независимых Государств (СНГ) увеличилось до около 5 000-7 000. Возможные мотивы этих ИБТ уже были упомянуты - одним из наиболее важных было желание бороться с российским государством и воевать против режима Асада. Но за кого они воевали? В целом, боевиков можно разделить на таких, которые находятся в союзе с ИГ, и таких, которые в союзе с ан-Нусра (т.е. Аль-Каидой). Однако, динамика этих союзов очень непростая, так как в ходе конфликта отдельные группы меняли союзников в результате внутригрупповой динамики, развития дел в КЭ и изменения отношений между ИГ и ан-Нусра.

\section{Джаиш аль-Мухджирин валь-Андсар (ДМА, Армия эмигрантов и помощников)}

Одной из наиболее известных джихадистских групп с изначально большим участием выходцев с Северного Кавказа является Джаиш аль-Мухаджирин валь-Ансар (ДМА, Армия эмигрантов и помощников). Как было упомянуто выше, она была сформирована в результате слияния нескольких других групп, ее руководство было чеченским и треть боевиков были выходцами с Северного Кавказа. Эта группировка играла важную роль в гражданской войне. Она участвовала в захвате стратегической инфраструктуры на севере, и известна своей военной отвагой, выдающимся руководством и аффилиацией с Аль-Каидой. Первым руководителем группы был Омар аль-Шишани,

44 Paraszczuk, "1st Imarat Kavkaz Amir In Syria Fought Alongside Gelyaev In Chechnya, Died Fighting Alongside Ahrar."

45 "Ahrar al-Sham," in Mapping Militant Organizations, updated August 5, 2017, http://web.stanford.edu/group/mappingmilitants/cgi-bin/groups/view/523. 
и он поддерживал связи с КЭ, так как группе был нужен «авторитет в Сирии», а Омару были нужны люди. Большинство мужчин, прибывших в Сирию с Северного Кавказа, были верны Умарову, и Омар Шишани говорил им, что он тоже присягнул лидеру КЭ. Согласно некоторым источникам, он попытался сохранить автономию ДМА как от ИГ, так и от ан-Нусра. ${ }^{46}$ Но всетаки, в марте 2013 года он обещал байа (верность) лидеру ИГ аль-Багдади вместе с некоторыми из своих людей. Это вызвало расцепление в ДМА многие лоялисты КЭ восприняли это как «предательство», и в то же время Омар обвинил Сайфулла в краже и такфир, выгнав его из ДМА. ${ }^{47}$ Большинство русскоговорящих боевиков стояли перед дилеммой: либо продолжать воевать независимо, либо остаться верными КЭ, либо произнести байа лидеру ИГ.

Позже Омар уйдет из ДМА и перекинется в ИГ в ноябре 2013, захватив множество боевиков с собой. Он станет выдающимся командиром одного из северных батальонов со многими русскоговорящими участниками. Подобным образом, когда Сайфулла был изгнан, многие северокавказские боевики последовали за ним и присоединились к Джунуд аль-Шам. ${ }^{48}$ В 2014 году ДМА присоединится к коалиции Ансар аль-Дин и позже присягнет на верность ан-Нусра. Салахуддин Шишани был эмиром ДМА и предположительно пытался сохранять нейтралитет между ИГ и ан-Нусра, и даже пытался содействовать достижению перемирия. В июне 2015 Салахуддин Шишани (являющийся также эмиром Имарата Кавказ в Шаме) был изгнан из ДМА, и вместе с верными ему и КЭ ИБТ ушел, чтобы создать Имарат Кавказ в Шаме. ${ }^{49}$ В том же году некоторые из русскоговорящих из ДМА присоединились к Катиба Сайфулла (группа с узбекским руководством, часть анНусра), чтобы сформировать Лива аль-Мухджирин, хотя об этой группе нет много информации. ${ }^{50}$ Муслим аль-Шишани, другой влиятельный ИБТ из Панкисского ущелья в Грузии, был лидером Джунуд аль-Шам, и тоже пытался сохранить независимость своей группы. Однако, в 2016 году, Джунуд аль-Шам распалась, и Муслим и большинство северокавказских боевиков

46 Joanna Paraszczuk, "Umar Shishani's Biographer Distances Him from Imarat Kavkaz Bayah," From Chechnya to Syria, August 1, 2016, www.chechensinsyria.com/?p= 25200.

47 Joanna Paraszczuk, "Khalid Shishani on Why Sayfullakh Shishani \& Umar Shishani Fell Out," From Chechnya to Syria, August 23, 2016, www.chechensinsyria.com/?p=25233.

48 "Jund al-Sham - Syria," Terrorism Research \& Analysis Consortium (TRAC), https://www.trackingterrorism.org/group/jund-al-sham-syria (21 August 2017).

49 Joanna Paraszczuk, "Salakhuddin Shishani Swears Bay'ah to New CE Emir," From Chechnya to Syria, July 9, 2015, http://www.chechensinsyria.com/?p=23921.

50 Joanna Paraszczuk, "'Umar from the Caucasus' is Emir of Nusra's Liwa al-Muhajireen Wal Ansar," From Chechnya to Syria, March 12, 2016, www.chechensinsyria.com/?p= 25032. 
стали членами Аджнад аль-Кавказ, которая предположительно была независимой от Кавказского эмирата. ${ }^{51}$ Салахуддин Шишани и его последователи в 2016 году сформировали новую группу, Джаиш аль-Усра. ${ }^{52}$ K 2017 году ДМА является частью Хайят Тахрир аль-Шам - последний новый бренд ан-Нусра, - которая заявляет, что связана с Аль-Каидой. 53

Большинство ИБТ с Северного Кавказа остаются с ИГ (главным образом из-за эффективной пропаганды ИГ), и следующая по численности группа связана с ан-Нусра (сейчас Хайят Тахрир аль-Шам). В обеих организациях имеются выходцы с Северного Кавказ на руководящих должностях. Те, кто верны ИГ, часто критикуют других (Ан-Нусра и связанные с Имарат Кавказ) за их «якобы нерешительность и национализм», тогда как те не одобряют ИГ и применяемое им чрезмерное насилие против гражданского населения.

Независимо от того, к кому присоединяются ИБТ с Северного Кавказа ИГ, ан-Нусра (сейчас Хайят Тахрир аль-Шам) или к другим группам, их репутация яростных бойцов следует за ними, - среди них большее число погибших, чем среди местных боевиков, и часто их считают «элитой». Кроме того, известно, что многие северо-кавказцы бросаются на передовую, не думая о том, как вернуться живыми. ${ }^{54}$ Упадок Кавказского эмирата оказал влияние на рассеяние ИБТ с Северного Кавказа по сирийскому театру военных действий. Особенно после 2014 года многие ИБТ присоединились к ИГ. Упадок КЭ позволил появление ИГ на Северном Кавказе. Хотя оно может использоваться местными боевиками только в качестве бренда заместителя, ИГ тем

51 Joanna Paraszczuk, "Interview \& Letter from Anjad al-Kavkaz Amir Abdul Hakim Shishani," From Chechnya to Syria, February 24, 2017, www.chechensinsyria.com/?p= 25309\#more-25309; и Joanna Paraszczuk, “Anjad al-Kavkaz Don't Have Bay'ha to Caucasus Emirate," From Chechnya to Syria, May 22, 2015, доступно на http://www.chechensinsyria.com/?p=23771.

52 Joanna Paraszczuk, "Salakhuddin Shishani is Emir of Jaish al-Usrah, Khayrullah Shishani Is His Deputy," From Chechnya To Syria, February 16, 2016, доступно на http://www.chechensinsyria.com/?p=24678.

53 Хайят Тахрир аль-Шам (ХТШ) сформировалась в результате слияния Джабхат Фатех аль-Шам (ан-Нусра), Фронта Ансар аль-Дин, Джаиш аль-Сунна, Лива аль-Хакк и движения Нур аль-Дин аль-Зинки 28 января 2017 года. В своем послании от 9 февраля 2017 года, лидер ХТШ Абу Джабир настаивал на том, что эта организация «является независимым субъектом, а не продолжением предшествовавших организаций или фракций». Это рассматривается как попытка дальнейшего дистанцирования организации от Аль-Каиды. Смотри ВВС Monitoring, "Tahrir al-Sham: Al-Qaeda's Latest Incarnation in Syria," BBC News, February 28, 2017, www.bbc.com/ news/world-middle-east-38934206; Thomas Joscelyn, "Hay'at Tahrir al Sham Leader Calls for 'Unity' in Syrian Insurgency," FDD's Long War Journal, February 10, 2017, https://www.longwarjournal.org/archives/2017/02/hayat-tahrir-al-sham-leadercalls-for-unity-in-syrian-insurgency.php.

54 Rao Komar, Christian Borys, and Eric Woods, "The Blackwater of Jihad," Foreign Policy, February 10, 2017, http://foreignpolicy.com/2017/02/10/the-world-first-jihadiprivate-military-contractor-syria-russia-malhama-tactical/. 
не менее располагает сетью для сегодняшнего и будущего использования. Кроме того, многочисленные «независимые» и связанные с ан-Нусра группы включают лица, которые длительное время участвуют в сирийском конфликте. Они приобрели опыт и связи, и их действия подпитываются мотивом борьбы против российского государства. Многих из них в будущем следует считать угрозой - на Кавказе или в зонах других конфликтов.

Такие лидеры с Северного Кавказа, как Омар аль-Шишани, часто используются как «лицо» пропаганды ИГ на русском с целью привлечения новых боевиков. Более того, согласно другим (не-ИГ) джихадистам, пропаганда ИГ оказалась исключительно эффективной в привлечении молодых людей из Кавказского региона, и к 2014 году их число почти удвоилось. Доклад Европол также ссылается на статью из российского ежедневника «Новая газета», в которой автор принимает за само собой разумеющееся, что ФСБ на самом деле содействовало отправке экстремистов из Чечни и Дагестана в Сирию для того, чтобы ограничить насилие в российском кавказском регионе. Кроме того, похоже, ведется пропагандистская война между связанными и несвязанными с ИГ русскоговорящими про-джихадистами (т.е. между ИГ и ан-Нусра), и которую ИГ, похоже, выигрывает. В письме, отправленном через Телеграм аккаунт Кавказского центра, Халид Шишани писал, что молодые люди с Северного Кавказа в целом забывают о настоящей природе «псевдо-халифата (ИГ)», и «объяснениях вебсайта Аль-Инсад и о таких теоретиках джихада, как Абу Катада аль-Филистини». ${ }^{55}$ Далее он предлагает расширить свою собственную пропагандистскую работу через использование аккаунтов разных социальных медиа с ожиданием получения постоянных запретов, потому, что «в Чечне большинство молодежи является сторонниками ИГ», и это вина разных эмиров, в том числе и его. 56 Члены не связанных с ИГ групп, например Абдул Хаким Шишани и Муслим Шишани, дали интервью разным вебсайтам, например Нохчичо. 57

В процессе конфликта в Сирии средства проджихадистской пропаганды совершенствовались. Медиа платформы стали более «профессиональными» и приспосабливались к потребностям целевой аудитории. Большая часть материалов публикуется на русском языке, что позволяет им доходить до очень широкой публики русскоговорящих лиц по всему свету. Несмотря на продолжающуюся войну пропагандистских про-ИГ и против-ИГ кампаний, первая до нынешнего момента была исключительно эффективной. В результате этого, многие молодые люди с Северного Кавказа легко поддавались радикализации и вербовке. Многие из них продолжают искать пути в ИГ на театр военных действий в Сирии, а другие совершают террористические нападения на Северном Кавказе (главным образом, в Дагестане и

55 Joanna Paraszczuk, "Khalid Shishani: IS is Winning the Propaganda War in Chechnya," From Chechnya to Syria, April 18, 2016, http://www.chechensinsyria.com/?p=25071.

56 Paraszczuk, "Khalid Shishani: IS is Winning the Propaganda War in Chechnya."

57 ИА Нохчийчоь, «Абдул-Хаким аш-Шишани: Мы выражаем поддержку акции 23 февраля», http://nohchicho.com/tribune/abdulhakim-about-23-february/. 
Чечне). Конечно, ан-Нусра и другие группы тоже приобретают новых рекрутов; однако, большая часть северокавказских ИБТ остается с ИГ. Более того, существующие каналы пропаганды способствуют созданию сетей из джихадистов, которые могут быть использованы в будущем.

\section{Значение ИБТ с Северного Кавказа для безопасности}

В настоящее время поток прибывающих в Сирию ИБТ уменьшился. Это результат усиленного пограничного контроля и высокого процента боевых потерь вооруженных групп. Те, кто прибыли в Сирию и Ирак в начале конфликта, по большей части не вернутся на Северный Кавказ, чтобы сражаться против российского государства. Как правило, это были боевики с военным опытом, которые были известны властям. Эти боевики проложили дорогу для себя и для боевиков в последующих годах, - создав или свои собственные «независимые» группы, как Абдул Хаким Шишани и Муслим Шишани, группы, аффилированные с КЭ, или такие, которые позже раскололись и сформировались соперничеством между ИГ и ан-Нусра.

Независимо от того, к какой группе они решили присоединиться, эти боевики могут оказаться большой угрозой для безопасности не только России, но и соседних стран, или зон будущих конфликтов. Новый боевой опыт приобретенный/или усовершенствованный, полученная подготовка, созданные сети и их репутация прибавляют им «опасной стоимости» - и потому увеличивают их способность вербовать новых рекрутов. Кроме того, факт, что на сирийском театре военных действий появилась частная военная компания Малхама Тактикал, опасен тем, что он может стать тенденцией. Из-за факта, что большинство ИБТ с Северного Кавказа руководствуются желанием сражаться с российским государством, их можно рассматривать, как «джихадистских интернационалистов», которые готовы переезжать в другие регионы из-за невозможности продолжать борьбу на Северном Кавказе. У некоторых из «независимых» групп имеется более четкая политическая программа, что может оказаться опасно для Кавказа и увеличивает их желание вернуться туда. В целом, влияние войны в Сирии и, в частности, идеологическое проникновение Исламского государства на Северный Кавказ вызывает растущее беспокойство, несмотря на наличие существенных сил безопасности в регионе.

\section{Нестабильность на Северном Кавказе}

В войне с повстанцами, терроризмом и боевиками на Северном Кавказе участвует, по крайней мере, три типа игроков: силовики (полиция/органы охраны правопорядка), боевики, которых иногда называют «лесными» («из леса», из-за места, где они прячутся), и «переговорщики» (посредники между органами охраны правопорядка и боевиками). Последние являются некими миротворцами, которые «выводят людей из леса» и ведут переговоры для достижения определенных соглашений между полицией и боеви- 
ками. По мнению Милашиной, журналистки «Новой газеты», таким способом российские власти узнают, кто уезжает из России, чтобы воевать в Сирии, и «они не беспокоятся о тех, кто уехал, их беспокойство вызывают те, кто может вернуться». 58

Трудно найти официальную актуальную статистику, касающуюся числа возвращающихся из Сирии боевиков или числа террористических заговоров или нападений, совершенных боевиками/повстанцами, аффилированными с ИГ. Число боевиков, которые вернулись на Северный Кавказ в 2015 году, по некоторым оценкам составляет 15-20 \% (или до 889 лиц). ${ }^{59}$ Так же, в публичном пространстве существует немного конкретной информации о контртеррористических мерах, операциях и результатах. Согласно заявлениям ФСБ, в 2015 году успешно были предотвращены 30 террористических нападений, и 770 «бандитов» ${ }^{60}$ и их соучастников предстали перед судом. В 2016 году число предотвращенных терактов дошло до 42. В число лиц, находящихся под судом, входят те, кто участвовал в преступлениях террористического характера, включая финансирование, вербовка новых членов и отъезд из страны с целью сражаться за границей.

Вебсайт «Кавказский узел» дает хронологию событий на Северном Кавказе. Согласно его информации, интенсивность сражений между силовиками (органы охраны правопорядка, Росгвардия) и боевиками (боевики, повстанцы) увеличилась. В 2016 году было 84 вооруженных столкновения, 23 взрыва, семь террористических нападений и 287 погибших в общей сложности. ${ }^{61}$ Для сравнения, в 2015 году было 87 вооруженных столкновений, шесть терактов и 258 жертв в целом. ${ }^{62}$ Результативность нападений, совершенных боевиками, тоже повысилась. В 2015 году, в среднем на 10 погиб-

58 Обобщение статьи Елены Милашиной в Новой газете на английском можно найти в Paul Goble, "Novaya Gazeta - FSB Helps Islamists from Russia Go to Syria, Only Worried When They Come Back," The Interpreter, July 31, 2015, http://www.interpretermag.com/novaya-gazeta-fsb-helps-islamists-from-russia-goto-syria-only-worried-when-they-come-back/.

59 В 2015 году директор ФСБ Александр Бортников заявил, что из Сирии и Ирака в Россию вернулись 889 боевиков. Смотри Максим Солопов, «Спецслужбы России вычислили сотни вернувшихся из Сирии и Ирака боевиков», RBK, 25 декабря 2015, https://www.rbc.ru/politics/25/12/2015/567bfdfd9a7947a3b3b c7387.

60 «Бандит» имеет более широкое значение и является общим термином для обозначения преступника, связанного с «бандой» или преступной организацией. В данном случае это слово используется для обозначения террористов, или лиц принимающих участие в террористической деятельности.

61 «Статистика жертв на Северном Кавказе по категориям за 7 лет», Кавказский Узел, по состоянию на 21 августа 2017, http://www.kavkaz-uzel.eu/articles/ statistika_jertv_2010_2016/; «Северный Кавказ: на фоне роста насилия в Чечне боевики стали действовать гораздо эффективней», Кавказский Узел, 6 апреля 2017, http://www.kavkaz-uzel.eu/articles/300522/.

62 «Северный Кавказ: на фоне роста насилия в Чечне боевики стали действовать гораздо эффективней». 
ших силовиков, боевики теряли 35 человек, в 2016 - на 10 погибших силовиков пришлось по 17 боевиков. Эта тенденция сохраняется до настоящего времени (апрель 2017). Эскалация ситуации в Чечне, провалы Росгвардии и возвращение боевиков из Сирии способствовали сохранению этой тенденции. В результате столкновений и КТО в 2016 были уничтожены 162 боевика (в том числе 22 командира «бандитского подполья» ${ }^{63}$ ), и четверо были ранены. За прошедшие три года эти числа постоянно уменьшались - 174 в 2015, 249 в 2014. До настоящего момента в 2017 году были уничтожены 17 боевиков в Чечне и 8 в Дагестане. ${ }^{64}$ Потери органов охраны правопорядка в 2016 году составляют 97 человек (32 погибших и 65 раненных), что почти в два раза больше, чем в 2015 (49). После 2015 года только в Чечне было 10 случаев нападений на силовиков (три в 2017, четыре в 2016 и три в 2015).

Нападения совершаются и в Ингушетии, Кабардино-Балкарии и Дагестане. Кроме того, ответственность за нападения в этом регионе все чаще берет на себя ИГ. В августе 2016 года ИГ выпустило видеоролик, призывающий к джихаду в России; однако, Кадыров, глава Чеченской республики, не воспринял его всерьез, заявив, что боевики ИГ не располагают ни силой, ни возможностями для этого. Тем не менее, еще в 2015 году ИГ приняло на себя ответственность за первые нападения на Северном Кавказе; нападение на казармы российской армии в Южном Дагестане и стрельба в Дербенте являются примерами тому. Некоторые из боевиков, принявших участие в этих нападениях, являются бойцами, которые вернулись из Сирии. ${ }^{65}$ В 2016 году имели место еще пять связанных с ИГ нападений в Дагестане и одно в Чечне. И наконец, в 2017 (к апрелю) ИГ связывалось с по крайней мере четырьмя нападениями, в том числе с нападением на контрольнопропускной пункт Росгвардии в конце марта и с двумя столкновениями с джихадистами в Чечне. Нападение, которое произошло в марте, может быть связано с видеороликом, опубликованном на Youtube за несколько дней до этого под именем «Совет военных джамаат Ичкерии», и который предположительно изображает некоторых из возвращающихся боевиков, бывшими членами ДМА.

Недавний теракт в Санкт-Петербурге, совершенный 3 апреля 2017 (взрыв в метро между двумя центральными метростанциями, при котором погибли 16 человек и были ранены 102), был первым терактом такого масштаба после 2013 года. Говорят, что подозреваемый террорист-самоубийца

63 «Бандитское подполье» используется для обозначения разных сетей и организаций повстанцев/боевиков, предположительно связанные с террористической деятельностью.

64 «Инфографика. Статистика жертв на Северном Кавказе в первом квартале 2017 года по данным Кавказского узла», Кавказский Узел, 17 апреля 2017, http://www.kavkaz-uzel.eu/articles/301176/.

65 «НАК: в Дагестане нейтрализованы два бандглаваря и боевик, вернувшийся из Сирии», РИА Дагестан, 29 ноября 2015, www.riadagestan.ru/news/incidents/nak v_dagestane_neytralizovany_dva_bandglavarya_i_boevik_vernuvshiysya_iz_sirii/. 
является этническим узбеком, рожденном в Кыргызстане. Он получил российское гражданство в 2011 году, жил и работал в Санкт-Петербурге. Согласно РБК, в декабре 2016 года он был депортирован из Турции. ${ }^{66} 25$ апреля 2017 SITE Intelligence Group объявил, что ответственность за нападение на себя взяла Катиба аль-Имам Шамиль, связанная с Аль-Каидой группа в Сирии. ${ }^{67}$ Некоторые эксперты так же предполагают, что исполнитель может быть связан с одним из руководителей КЭ в Кабардино-Балкарии, который согласно Национальному антитеррористическому комитету (НАК) был уничтожен в ходе КТО в Санкт-Петербурге ранее в августе 2016 вместе с другими четырьмя известными членами.

Надо иметь в виду, однако, несколько моментов. Нападения, за которые берет на себя ответственность ИГ, не обязательно совершаются боевиками, которые возвращаются из Сирии или Ирака. ИГ проникло на Северный Кавказ, и многие молодые люди (под влиянием пропаганды ИГ и из-за условий в регионе) подвергаются радикализации, не уезжая сражаться за границей. Слово «боевики» - бойцы/повстанцы - не отражает различия в виде или аффилиации боевиков (Кавказский эмират, Исламское государство или другие) и используется в качестве синонима слова «террорист». КЭ сейчас едва существует благодаря КТО, проведенным правительственными силами в 2016 году, и образовавшуюся пустоту заполнило ИГ. По крайней мере, одно из нападений в Чечне можно связать с боевиками, которые вернулись из Сирии и которые были членами ДМА. С боевиком, вернувшимся из Сирии, связывается и другое нападение в Дагестане. Кроме того, многие вернувшиеся боевики уже присоединились к «бандитскому подполью», хотя числа пока неизвестны.

\section{Что делать с ИБТ: коллективная ответственность}

За последние три года российское законодательство по борьбе с терроризмом 68 и обеспечению общественной безопасности было дополнено но-

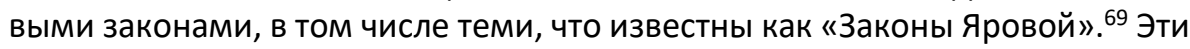
законы расширили спектр преступлений, классифицируемых как террори-

66 Игорь Залубовин, «Призрак террориста. По следам Акбара Джалилова, взорвавшего метро», Сноб, 12 апреля 2017, https://snob.ru/selected/entry/123174.

67 Артем Филипенок и Анжелика Басисини, «Ответственность за теракт в метро взяла связанная с «Аль-Каидой» группа», РБК, 25 апреля 2017, https://www.rbc.ru/ society/25/04/2017/58ff6c359a7947167d4fdcd4; and SITE Intelligence Group, "Alleged AQ-Linked Group Claims St. Petersburg Metro Bombing," April 25, 2017, https://news.siteintelgroup.com/Jihadist-News/alleged-aq-linked-group-claims-stpetersburg-metro-bombing.html.

68 Соответствующие законы перечислены на вебсайте Национального антитеррористического комитета, http://nac.gov.ru/zakonodatelstvo/zakony.html.

69 Валерия Зеновина, «Президент РФ подписал антитеррористический 'пакет Яровой'», Гарант.ру, 7 июля 2016, www.garant.ru/news/782190/. 
стические. Были введены новые положения, например, введение уголовной ответственности за недоносительство о преступлениях террористического характера, за совершение актов международного терроризма и о мониторинге электронных сообщений. Кроме того, в них были определены дополнительные меры: среди прочих, правила для телекоммуникационных компаний и компаний поставщиков интернета по сохранению данных, запрет на миссионерскую и экстремистскую деятельность. Некоторые из этих законов стали объектом споров, касающихся ограничений прав человека и возможной неконституционности. ${ }^{70}$ Однако, они являются прямой реакцией на проблему российских боевиков в Сирии и внутренней террористической ситуации. Максимальным наказанием по этим законам является пожизненное заключение. Предполагается, однако, что Северный Кавказ живет по несколько различным законам.

Как конкретно местные власти на Северном Кавказе справляются с боевиками, возвращающимися в регион, покрыто тайной и не вполне ясно. Официально, региональный подход основывается на российском контртеррористическом законодательстве (Федеральный уголовный кодекс и другие антитеррористические законы $\left.{ }^{71}\right)$, и службы безопасности проводят регулярные КТО. Особый интерес, однако, вызывает концепция коллективной ответственности и другие меры, направленные на широкую общественHOCTb.

Принцип коллективной ответственности в наше время воспринимается отрицательно, поскольку он предполагает, что ответственность возлагается на группу невиновных лиц, которые не связаны с преступлением. Но в настоящее время этот принцип применяется в Чечне для контролирования населения, и в более широком смысле, для осуществления репрессий. Как информирует Кавказский узел, в 2016 году с помощью этого метода (в сочетании с активными визитами Кадырова в разные государства Ближнего Востока и финансированием строительства мечетей и школ) влияние чеченского правительства на чеченскую диаспору внутри и за границами России ощущается все сильнее. По словам защитников прав человека Сокирянской, Орлова, Локшиной и Ганушкиной, чеченские беженцы не забывают, что у них все еще имеются «подверженные давлению» родственники в Чечне, что иногда становится причиной для их возвращения на родину.

70 «Положения антитеррористического законодательства, ограничивающие права граждан, Мониторинг новых российских законов и их правоприменение в области гражданских прав, http://monitoring.mhg.ru/zakon15.

71 К тем, кто вернулся из Сирии, часто применяется Параграф 208, п. 2 Уголовного кодекса Российской Федерации. Он касается заключения под стражу за «участие в вооруженных формированиях на территории иностранного государства с целями, противоречащими интересам Российской Федерации». С другой стороны, параграф 205 касается терроризма. Законы Яровой вызвали массовое общественное недовольство и привлекли внимание Амнести интернешнл к предполагаемым нарушениям прав человека. 
Согласно Орлову, в настоящее время Кадыров активно работает для законодательного закрепления принципа коллективной ответственности на федеральном уровне, - и на некоторых местных ток-шоу можно услышать, что этот принцип является нормой (хотя «всего лишь пару лет назад он считался варварским»). В Чечне главным доводом для применения принципа коллективной ответственности, однако, являются борьба с терроризмом, экстремизмом и радикализацией, борьба против повстанцев и бойцов вооруженного сопротивления (так называемых «боевиков»). Российский уголовный кодекс не признает коллективную ответственность. Согласно одному из антитеррористических «Законов Яровой», ${ }^{72}$ с 20 июля 2016 года увеличивается уголовная ответственность за преступления террористического характера (начиная с возраста в 14 лет), в том числе за недоносительство о действиях (совершенных или совершаемых) террористического характера. ${ }^{73}$ Максимальным наказанием за утаивание информации является заключение сроком на один год, и оно не применяется для супругов или близких родственников; однако, их можно привлекать к материальной ответственности за какой-либо ущерб, нанесенный террористическим нападением. ${ }^{74}$ Несмотря на это, российские власти «закрывают глаза» на применение Кадыровым коллективной ответственности в Чечне и на остальном Северном Кавказе. По словам Кадырова, семьи боевиков, ответственных за уголовную деятельность, будут выселяться из республики, а их дома разрушаться «до оснований». ${ }^{75}$

Коллективная ответственность является не только предпочитаемой официальной стратегией, похоже, ее поддерживают и простые граждане (из страха перед властями или по иным причинам). В декабре 2016 и январе 2017, в ответ на нападения в Дагестане и Чечне, правительственные силы осуществили массовый «рейд» задержаний и допросов родных и друзей устраненных боевиков. По имеющимся сведениям, были задержаны около

72 Не все применяются в настоящее время - некоторые вошли в силу с 20 июля 2016, другие начнут применяться с 2018 года.

73 В их число входит получение образования с целью осуществления террористической деятельности, участие в террористической сети, участие в террористической организации, акты международного терроризма и несколько других. Для дополнительной информации смотри Федеральный закон N 375-Ф3 от 6 июля 2016, http://www.garant.ru/hotlaw/federal/782193/.

74 Peter Roudik, "Russia: Collective Responsibility for Acts of Terrorism," Global Legal Monitor, December 24, 2014, http://www.loc.gov/law/foreign-news/article/russiacollective-responsibility-for-acts-of-terrorism/.

75 Это заявление было сделано в декабре 2014 года, в нем осуждались действия боевиков, которые напали на местную полицию, убив 14 полицейских и ранив других. После заявления, по информации центра по правам человека «Мемориал", в декабре 2014 около 14 домов было сожжено, и их обитатели были выселены из Чечни. Для дополнительной информации смотри Елена Милашина, «Угроза пустить пулю в лоб не является чем-то незаконным?», Новая газета, 13 декабря 2014, https://www.novayagazeta.ru/articles/2014/12/13/62349-ugrozapustit-pulyu-v-lob-ne-yavlyaetsya-chem-to-nezakonnym. 
200 людей, в том числе малолетние. Согласно Маазу Билалову, все родственники боевиков, участвующих в нападениях в декабре, были уволены с работы и их пенсии и социальные пособия не выплачивались. После январских нападений на чеченскую полицию/Росгвардию, некоторые из родственников боевиков подверглись публичному осуждению, иногда с использованием местных СМИ (телевизионные каналы, например), и были вынуждены оставить свои дома в Чечне. ${ }^{76}$ Более того, родственники погибших сотрудников полиции призывали к кровной мести. Согласно обычаю, родственники убитого обязаны отомстить убийце или его родственникам. Традиционно, среди народов Северного Кавказа кровная месть служила для регулирования общественных отношений, защиты чести и собственности семьи. ${ }^{77}$ Для кровной мести не было “срока давности», она должна была быть объявлена через «посредника» и была направлена на преступника или его близких родственников по мужской линии. Это традиция не новая, но ее применение (полу-) сдерживалось самым Кадыровым. Говорят, что в ответ на угрозу объявления кровной мести все мужчины из рода Бахарчиева уехали из Чечни. ${ }^{78}$

8 января 2017 года в Грозном, Чечня, состоялся протест против ИГ и его лидера аль-Багдади, на котором собралось около 2000 людей, в основном простые граждане. Среди выступавших с речами были матери боевиков, которые присоединились или собирались присоединиться к ИГ. Они публично просили прощения за преступления своих сыновей. Обсуждалась также ответственность родителей - люди пришли к согласию, что родители должны использовать более строгие методы и должны улучшить воспитание своих детей. Одним из ораторов, принимавшим участие в протесте, был вернувшийся боевик Саид Мажаев. Он сдался властям по возвращению из Сирии через Турцию в 2014 году и был амнистирован в результате соглашения с властями - согласно которому, очевидно, он должен был участвовать в разных формах контр-нарративов и анти-ИГ пропагандисткой работы с молодежью республики. ${ }^{79}$ Поэтому Саид Мажаев часто появлялся в мечетях, школах и университетах, давал интервью газетам и телевизионным каналам, и рассуждал об опасности ИГ (на деле он воевал за ДМА и уехал из Сирии до того, как Омар Шишани официально присоединился к ИГ). По имеющимся сведениям, Мажаев действительно смог убедить некоторых людей

76 Kazbek Chanturiya, "Collective Responsibility in Chechnya; An Ineffective Method of Influence," OCMedia, January 19, 2017, http://oc-media.org/collective-responsibilityin-chechnya-an-ineffective-method-of-influence/.

77 «Кровная месть - как теперь убивают на Кавказе», Кавказский узел, 26 декабря 2017, http://www.kavkaz-uzel.eu/articles/296137/.

78 «Односельчане потребовали выселить из Чечни семью предполагаемого боевика», Кавказский узел, 22 декабря 2017, http://www.kavkaz-uzel.eu/articles/ 294735/.

79 Chanturiya, "Collective Responsibility in Chechnya; An Ineffective Method of Influence." 
не присоединяться к ИГ, но среди участвующих в нападении в Грозном в декабре 2016 был его младший брат. ${ }^{80}$ Протест против ИГ закончился сожжением портретов аль-Багдади. Другими публичными событиями, служащими платформой для «обсуждения» таких стратегий, как коллективная ответственность, являются городские митинги, организуемые часто после нападений или столкновений.

Задача таких протестов состоит в том, чтобы вызвать у населения страх, давая ему понять, что участие в террористической деятельности имеет последствия, в том числе и для родственников. Принцип коллективной ответственности не нов и применялся давно местными властями и российскими специальными силами в их борьбе с повстанческими движениями на Северном Кавказе. Сильное давление оказывается на всех родственников по мужской линии, «вплоть до троюродных братьев» с отцовской стороны. Часто это означает исчезновения, допросы, избиения и пытки. Иногда родственники используются как живой щит, чтобы убедить боевика «выйти из леса» или перейти на сторону правительства. Несмотря на факт, что коллективная ответственность является неэффективной стратегией в плане устранения основных причин социальных проблем (на деле, это только их усиливает), она успешно применяется чеченскими властями.

\section{Заключительные замечания}

Подходы для борьбы с терроризмом и экстремизмом на Северном Кавказе подпитывают существующую социальную нестабильность, обиды и недовольство властями в регионе. Российскому государству следует разработать более мягкие подходы для противодействия терроризму. В результате многолетних КТО и контртеррористических стратегий (в том числе и «коллективная ответственность») Кавказский эмират практически распался и в настоящее время почти не функционирует. Однако, это объясняется и расширением влияния ИГ в этом регионе. Пропаганда ИГ успешно находит свою аудиторию среди северокавказской (и шире, российской) молодежи, агитируя их ступить на путь джихада в России или за ее границами. Число ИБТ из России и других государств СНГ хотя и уменьшается в настоящее время, все еще остается большим (5000-7000) и, по некоторым сведениям, российские силы особого назначения, возможно, в прошлом способствовали потоку отбывающих боевиков. Хотя число боевиков, возвращающихся в регион из Сирии, точно неизвестно, их может быть около 15-20 \%. Те, кто возвращаются, либо предстают перед судом, либо задерживаются, некоторые присоединяются к подпольным сетям, или их местонахождение неизвестно.

Число связанных с ИГ терактов на Северном Кавказе увеличилось, и некоторые из последних нападений связываются с бывшими боевиками из ДМА и другими возвращенцами из Сирии. Остающиеся в Сирии и Ираке бо-

80 Chanturiya, "Collective Responsibility in Chechnya." 
евики и те, кто только еще пытается присоединиться к ним на театре военных действий, являются угрозой не только для России, но и для соседних с ней государств. Мотивом их действий является желание сражаться с российским государством везде, где это возможно. При нынешнем развитии конфликта в Сирии и ухудшении ситуации и репрессий в Чечне и соседних республиках, этот мотив становится только сильнее. Первую волну ИБТ можно считать более опасной, так как они сумели обеспечить себе репутацию, использовать эту репутацию и расширить свой опыт, умения и связи. Это они утвердили себя на поле сражений, сформировав разные джамаaт, и в одном случае даже «джихадистскую частную военную компанию». Вторая волна боевиков с Северного Кавказа была сформирована в основном под влиянием пропаганды ИГ, которое сохраняет свое влияние в регионе, несмотря на организационные проблемы в Сирии и Ираке. Вне зависимости от своей аффилиации, ИБТ с Северного Кавказа являются долгосрочной угрозой для глобальной безопасности. Если представится возможность, они будут воевать в основном на Кавказе, но если не смогут вернуться домой, они готовы нападать в каком-либо другом месте. 